\title{
FISKALNE ASPEKTY LEGALIZACJI MIĘKKICH NARKOTYKÓW. DOŚWIADCZENIA STANÓW ZJEDNOCZONYCH AMERYKI PÓŁNOCNEJ
}

\begin{abstract}
Streszczenie. W ostatnich latach zaobserwowano zmianę podejścia administracji federalnej Stanów Zjednoczonych Ameryki Północnej do zagadnienia zażywania marihuany. Nastąpiło przejście od wojny pochłaniającej wiele ofiar, do faktycznego pozostawienia decyzji o legalizacji marihuany poszczególnym stanom. Autor opisuje wskazany proces, przedstawia kontrowersje, jakie wywołał przełomowy wyrok w sprawie Gonzales v. Reich, analizuje status prawników z branży narkotykowej (tzw. „marijuana lawyers”), wskazuje na proces planowania podatkowego w aspekcie handlu marihuaną, a także przedstawia skalę osiąganych przez podmiot publicznoprawny zysków z obłożenia zażywania marihuany podatkami obrotowymi, oraz z nałożenia podatków dochodowych na dochód dealerów i podmiotów z nimi współpracujących.

Słowa kluczowe: planownie podatków, marihuana, przemysł narkotykowy, Gonzales v. Reich, marijuana lawyers.
\end{abstract}

\section{WPROWADZENIE}

Legalizacja miękkich narkotyków pociąga za sobą skutki nie tylko społeczne i zdrowotne, ale także fiskalne. Wskazane oddziaływanie może przybrać dwojaki charakter: $z$ jednej strony budżet państwa zostaje odciążony poprzez zmniejszenie środków przeznaczanych na zwalczanie części przemysłu narkotykowego oraz na późniejsze egzekwowanie kar pozbawienia wolności. Przed podmiotem publicznoprawnym otwierają się także zupełnie nowe możliwości legalnego - zatem możliwego do opodatkowania - osiągania dochodu przez rezydentów, podlegających jego jurysdykcji podatkowej. Doświadczenia Stanów Zjednoczonych są przy tym niezwykle cenne dla państw europejskich. Dzięki fundamentom unijnej integracji - swobodnym przepływom osób, towarów i usług, kapitału, płatności - ułatwiono wymianę handlową i współpracę gospodarczą pomiędzy podmiotami z poszczególnych państw, a międzynarodowe planowanie podatkowe w perspektywie europejskiej stało się właściwie pozbawione barier. Podobne skutki ekonomicznego

\footnotetext{
*Uniwersytet Łódzki, Wydział Prawa i Administracji, atim@marianskigroup.pl.
} 
zbliżania się różnych terytoriów oraz ich mieszkańców zostały już zaobserwowane w Stanach Zjednoczonych Ameryki Północnej - także w aspekcie handlu narkotykami. Autor pragnie zaznaczyć, iż w niniejszym artykule zostaną zarysowane wyłącznie zagadnienia związane z wpływem legalizacji miękkich narkotyków na przychody osiągane przez podmiot publicznoprawny oraz z relacją prawa federalnego do prawa stanowego w tym przedmiocie. Zagadnienie zasadności procesu legalizacji zażywania marihuany pozostawione zostaje do przedyskutowania w drodze dyskursu politycznego, a przedstawiony punkt widzenia może stanowić jeden $\mathrm{z}$ wielu wysuwanych argumentów.

\section{DROGA OD „WOJNY O ZDROWE SPOŁECZEŃSTWO” DO CZEŚSCIOWEGO PRZYZWOLENIA}

Szkodliwy wpływ niektórych substancji na zdrowie człowieka został zauważony już w czasach starożytnych i niejednokrotnie stanowił asumpt do interwencji legislacyjnej w celu ochrony porządku publicznego (Hoffman 2000, 1454) ${ }^{1}$. Handel używkami jest jednak doskonałym przedmiotem do opodatkowania, a wyjęcie spod obrotu niektórych kategorii produktów wiąże się ze znacznymi stratami dla budżetu struktur państwowych. Warto wskazać, że w amerykańskiej literaturze podkreśla się związek pomiędzy czasami prohibicji a Wielkim Kryzysem (tamże, 1456). Dostrzegając tę zależność, w ostatnich latach w Stanach Zjednoczonych władze federalne gwałtownie zmieniły swoje podejście do problemu miękkich narkotyków. W 1970 roku Kongres uchwalił Controlled Substances Act (21 U.S.C. $\$ 801$ et Seq. 2002)2, dzieląc tym samym ,substancje kontrolowane” na pięć kategorii. Marihuana została zakwalifikowana do pierwszej z nich, oznaczającej wysokie ryzyko uzależnienia oraz brak bezpiecznego lub możliwego do zaakceptowania użytku medycznego (Shasnky 2007, 770). CSA stanowiła regulację niezwykle surową, będącą fundamentem prowadzonej przez rząd wojny, pochłaniającej nie tylko ogromne środki finansowe (12,6 miliarda dolarów w 2005 r.) (Echegaray 2006, 1215), ale także ofiary śmiertelne (tamże, 1231) . Wystarczy przytoczyć tylko, że jeśli skutkiem zażycia heroiny lub kokainy była śmierć albo ciężki uszczerbek na zdrowiu, to dealerowi groziła kara pozbawienia wolności nie krótsza niż 20 lat (Echegaray, 1232), a samo posiadanie większej ilości twardych narkotyków zagrożone było karą pozbawienia wolności od 5 do nawet 40 lat. alkoholu.

${ }^{1}$ Kodeks Hammurabiego zabraniał ,pijaństwa”, aczkolwiek nie sankcjonował posiadania

${ }^{2}$ Zwana dalej: CSA.

${ }^{3}$ W ramach sankcji za naruszenie postanowień CSA, umożliwiono sądom w kilku wypadkach dokonanie skazania nawet na karę śmierci. 
W odniesieniu do przestępstw narkotykowych związanych z marihuaną przewidziano mniej surową regulację - maksymalny wymiar kary za przestępstwa drugiego stopnia wynosił 10 lat. Tak restrykcyjne środki zostały bezskutecznie podjęte, by zlikwidować drugi na świecie pod względem generowanych zysków nielegalny biznes (Gierach 1993, 95)4.

W czasie obowiązywania CSA kilka stanów ustanowiło regulacje legalizujące używanie marihuany w celach medycznych i pod nadzorem lekarza. Kalifornijski Compassionate Use Act (California Health \& Safety Code, § 11362.5(d), West Supp. 2006) z 1996 roku dopuszczał nie tylko samo zażywanie marihuany, ale także jej uprawianie - pod warunkiem jednak późniejszego wykorzystywania zbiorów w celach leczniczych. Pojawiła się zatem daleko idąca sprzeczność pomiędzy normami prawa federalnego, ustanawiającymi surowe sankcje za posiadanie marihuany, a normami prawa stanowego, zezwalającymi na użytek w celach medycznych. Konflikt ten został ostatecznie rozwiązany w 2005 roku, gdy Sąd Najwyższy USA wydał precedensowe orzeczenie w sprawie Gonzales v. Reich (545 U.S. $1 / 2005)^{5}$. Niezwykle kontrowersyjny i krytykowany w doktrynie (Shasnky 2007, 797) wyrok przyznawał władzom federalnym kompetencję do bezwzględnego stosowania CSA, nawet jeśli prawo stanowe zezwala na dokonywanie pewnych czynności związanych z marihuaną. Wyrok ten zapadł na kanwie wyrazistego stanu faktycznego - w rozpoznawanej sprawie pani Angel Reich cierpiała z powodu nieoperowalnego guza mózgu, objawiającego się zagrażającym życiu spadkiem wagi, nudnościami i chronicznym bólem. Stosowane leki przeciwbólowe pozostawały nieskuteczne, dlatego lekarz - opierając się na brzmieniu regulacji stanowej - zalecił jej zażywanie marihuany (Carcieri 2004, 316). Wobec okoliczności faktycznych, wzbudzających silne emocje, wyrok wywołał oburzenie nie tylko polityków stanowych, liczących na zyski z lokalnych podatków, ale także wśród społeczeństwa - odmawiał bowiem prawa do uprawiania i zażywania marihuany w celach medycznych, gdy nie istniała inna możliwość ulżenia człowiekowi w cierpieniu.

W obliczu fali krytyki, administracja federalna samoograniczyła się w wykorzystywaniu przyznanych uprawnien. Prokurator Generalny, Eric Holder, ogłosił na początku 2009 roku stanowisko dotyczące zmian w egzekwowaniu federalnej CSA w odniesieniu do zażywania marihuany w celach leczniczych. Stosownie do wyrażonego zapewnienia, administracja federalna zobowiązała się korzystać z przyznanych uprawnień tylko w przypadku konieczności reagowania na nadużycia szczególnego rodzaju - gdy stanowe regulacje będą wykorzystywane ,jako tarcza” dla przestępczej działalności (Johnston, Lewis 2009). Oświadczenie to spowodowało gwałtowny wzrost liczby uchwalanych aktów na poziomie stanowym, legalizujących posiadanie i zażywanie marihuany. Jednocześnie

\footnotetext{
${ }^{4}$ Na pierwszym miejscu umieszczono handel bronią.

${ }^{5}$ Zwany dalej: Reich.
} 
nakładano na konsumentów odpowiednie podatki (Leff 2014, 525-526). Zaobserwowana reakcja dotyczyła nie tylko politycznych decydentów i stanowych nowości normatywnych, ale także lokalnych przedsiębiorców. Wystarczy podać przykład gwałtownego wzrostu liczby placówek otwarcie prowadzących w Kolorado i Kalifornii działalność w przedmiocie handlu marihuaną w celach medycznych (Kamin, Wald 2013, 881). Fenomen ten był podsumowywany stwierdzeniem, że w ciągu stosunkowo krótkiego okresu, na terenie tych stanów powstało więcej placówek zajmujących się dystrybucją marihuany w celach medycznych aniżeli sklepów sieci Starbucks (tamże, 881).

Stan prawny, utrwalony orzeczeniem w sprawie Reich, stanowi jednak najpoważniejsze zagrożenie dla businessmanów zajmujących się przemysłem narkotykowym - angażowanie się w tego typu działalność obarczone jest nadal pewnym ryzykiem (tamże, 881). Warto podkreślić, że dokonaną zmianę w stosunku organów administracji publicznej do zagadnienia używania marihuany można określić wręcz jako rewolucyjną, biorąc pod uwagę surowość kar przewidywaną przez CSA oraz zaobserwowane przejście od restrykcyjnie przestrzeganych postanowień norm prawa federalnego do faktycznego (ale nie prawnego) pozostawienia decyzji o legalizacji miękkich narkotyków poszczególnym stanom, która to decyzja coraz częściej przybiera formę legalizacji także użytku rekreacyjnego marihuany (Leff 2014, 525) .

\section{3. "GARNEK ZLOTA” W WARUNKACH KRYZYSU EKONOMICZNEGO}

Przemysł narkotykowy umożliwia osiąganie znacznych zysków - w Afganistanie uprawy opium pozwalają na finansowanie działań Talibów. Uprawy haszyszu i marihuany zapewniają Hezbollahowi środki niezbędne do prowadzenia operacji w Libii i Syrii (Borden 2013, 231; Yanower 2013). Występowanie zysku na takim poziomie - umożliwiającym, w zorganizowanej formie, tworzenie struktur quasi-państwowych - w połączeniu z przybraniem legalnej formy jego osiągania, stanowi nie tylko atrakcyjne źródło dochodu dla dealerów, ale także bezcenny w warunkach kryzysu ekonomicznego przedmiot opodatkowania, określany w amerykańskiej doktrynie jako, ,garnek złota” (Vitiello 2009, 1349-1389)7. Należy zaznaczyć, iż przychód uzyskiwany jest przy tym nie tylko przez osoby bezpośrednio zaangażowane $\mathrm{w}$ rozprowadzanie i uprawę narkotyków, ale także przez podmioty współpracujące z tego typu uczestnikami rynku, bowiem „kiedy mari-

${ }^{6}$ Pierwszymi stanami, które zalegalizowały używanie marihuany w celach medycznych, były Kolorado i Waszyngton. Zob. Colo. Const. art. XVII § 16; Wash. Initiative Measure No. 502 (July 8, 2011).

${ }^{7} \mathrm{~W}$ języku potocznym wyrażenie to oznacza także: ,trawka złota”. 
huana wychodzi z cienia na półki sklepowe - staje się biznesem" (Kamin, Wald 2013, 870). Szacuje się, że w 2010 roku 17,4 miliona Amerykanów zażyło marihuanę. Liczba ta odpowiada liczbie ludności Holandii (EUROSTAT). W przypadku zupełnego zalegalizowania - liczba osób zażywających marihuanę w Stanach Zjednoczonych miałaby wzrosnąć nawet do 60 milionów (Evans 2013, 13). Dokonywanie konsumpcji na tak znaczącym poziomie stanowi atrakcyjny przedmiot opodatkowania nie tylko podatkami dochodowymi, ale także podatkami obrotowymi - podatkiem akcyzowym oraz od towarów i usług. Roczne przychody stanu Kalifornia z tytułu podatku dochodowego, pobieranego wyłącznie od podmiotów bezpośrednio zaangażowanych w handel miękkimi narkotykami, oraz z tytułu podatku pośredniego, pobieranego od uncji sprzedanej marihuany, są szacowane na przeszło 1 miliard 200 milionów dolarów (Vitiello 2009, 1353-1354). Roczne przychody budżetu stanu Kolorado, generowane przez podatki i opłaty związane z przemysłem narkotycznym, są szacowane na nawet $100 \mathrm{mln}$ dolarów (ten niewielki stan zamieszkiwało w 2014 roku nieco ponad pięć milionów mieszkańców) (Evans 2013,3). Warto wspomnieć, że stany dopuszczające zażywanie marihuany wyłącznie dla celów medycznych także opodatkowują dokonywaną konsumpcję i generowany dochód. W obliczu wielkiego finansowego potencjału sektora narkotykowego, siłom politycznym trudno pozostać obojętnym na możliwości uzyskania znacznego przychodu.

Przemysł narkotykowy w Stanach Zjednoczonych, choć formalnie nadal penalizowany przez prawo federalne, co znalazło wyraz w przytaczanym orzecznictwie Sądu Najwyższego USA, stanowi źródło dochodu także dla innych branż, wśród których szczególnie interesujący wydaje się być status prawników. W doktrynie zadaje się wręcz prowokacyjne pytanie - czy prawnicy branży narkotykowej (,,marihuana lawyers”) są wojującymi o ideę krzyżowcami („,crusaders”), a może raczej powinni być traktowani jak „outlaws” - wyjęci spod prawa najemnicy (Kamin, Wald 2013, 869-931). System common law zna bowiem zarówno konstrukcję odpowiedzialności pomocnika (accomplice liability), jak i odpowiedzialności współkonspiratora (coconspirator liability) - z uwagi jednak na podkreślane znaczenie „amerykańskiego indywidualizmu", instytucje te posiadają określone cechy szczególne w odniesieniu do konstrukcji europejskich (tamże, 886). Doktryna amerykańska stoi na stanowisku, że badanie stanu świadomości osoby świadczącej usługi, które są następnie wykorzystywane do działalności przestępczej (np. sprzedawcy paliwa, który wie, że jego kontrahent to seryjny podpalacz), jest nieistotne. Należy raczej ustalić, czy wobec wszystkich klientów taki podmiot świadczy takie same usługi - niezależnie od ich planów (tamże, 889). Jeśli tak, co do zasady wykluczona zostanie odpowiedzialność karna sprzedawcy jako pomocnika (People v. Lauria, 251 Cal. App. 2d 471 (Cal. Ct. App. 1967)) $)^{8}$. Takie stwierdzenia nie oznaczają jednak, że pomocnictwo stanowi martwą instytucję systemu amerykańskiego. Dla

\footnotetext{
${ }^{8}$ Cytowany w: Kamin, Wald 2013, 889.
} 
przypisania pomocnikowi oraz członkowi conspiracy odpowiedzialności karnej, kluczowe może być bowiem ustalenie istnienia „prawdziwego zamiaru” (true intent) (tamże, 889). Także analiza uregulowania dotyczącego odpowiedzialności za zaniechanie nie dostarcza argumentów przemawiających za szerszą odpowiedzialnością świadczącego usługi, który wie, że są one wykorzystywane do działalności przestępczej. Jeśli bowiem wyraźnie nie nałożono obowiązku o określonej treści na dany podmiot - nie można mówić o zaniechaniu i ewentualnej odpowiedzialności karnej. Prawo amerykańskie nie przewiduje wymogu bycia „dobrym samarytaninem" - obowiązku niesienia pomocy lub odpowiadania na naruszenia prawa, jeśli można zareagować bez narażania siebie na ryzyko (tamże, 889). Powyższe stwierdzenia są niezwykle istotne przy analizowaniu statusu marijuana lawyers. Problematyczne jest bowiem ustalenie, czy w obliczu istotnej niezgodności pomiędzy prawem stanowym a prawem federalnym, prawnik powinien pozostawać wierny regulacji federalnej i powstrzymywać się od doradzania podmiotom z branży narkotykowej. Wspomniane zagadnienie ma szczególne znaczenie po wydaniu tak znaczącego orzeczenia jak to zapadłe w sprawie Reich. W przypadku udzielania porad przedsiębiorcom z sektora narkotykowego zarówno prawnik, jak i np. księgowa prowadząca księgi rachunkowe czy wypełniająca deklaracje podatkowe, ponosiliby ryzyko podlegania karze na mocy prawa federalnego. Wskazane uwagi tyczą się również m.in. podmiotów wynajmujących pomieszczenie dla potrzeb sklepu $\mathrm{z}$ marihuaną. W doktrynie podkreśla się, że w takich przypadkach wymóg istnienia true intent jest ważnym środkiem obrony prawników branży narkotykowej przed oskarżeniem (tamże, 897). Wykazanie bowiem samej wiedzy o świadczeniu usług na rzecz podmiotów wykorzystujących je do działalności przestępczej (na gruncie prawa federalnego) nie wystarczy do poniesienia odpowiedzialności karnej. Warto podkreślić, że w przeciwnym razie sama wiedza o legalnym na gruncie prawa stanowego prowadzeniu sklepu z marihuaną i dostarczanie takiemu podmiotowi energii elektrycznej warunkowałyby odpowiedzialność bądź za pomocnictwo, bądź nawet za udział w conspiracy, mającym na celu łamanie regulacji rangi federalnej.

Powyższy problem był także analizowany na gruncie zasad etyki. Ciekawe stanowisko zostało zaprezentowane w opinii State Bar of Arizona, w której podkreślono, iż usługi prawne są wręcz niezbędne do stosowania postanowień bezpośrednio wyrażonych w prawie stanowym. Rola prawnika jest tym bardziej istotna, jeśli zachodzi konflikt pomiędzy prawem rangi stanowej a prawem rangi federalnej. W opinii podkreślono, iż historia jest pełna przypadków, w których dzięki zaangażowaniu prawników w sprawy o dużym stopniu skomplikowania i niekiedy niezgodności z prawem wyższego rzędu, doprowadzono do poszanowania praw, niemogących być $\mathrm{w}$ inny sposób zagwarantowanymi jak tylko przez argumentację prawną . $Z$ tego też względu, prawnicy nie powinni powstrzymywać się od

${ }^{9}$ Zob.: opinia State Bar of Arizona, Formal Op. 11.01(2011), przywołana w: Kamin, Wald 2013, 904 
reprezentowania podmiotów profesjonalnie zaangażowanych w uprawę i handel marihuaną, o ile tylko prawo stanowe zezwala na dokonywanie takich czynności. Stanowisko takie jest niezwykle korzystne dla profesjonalnych pełnomocników i doprowadziło do umożliwienia legalnego partycypowania w korzyściach, jakie przynosi biznes narkotykowy.

W aspekcie fiskalnym omawianej problematyki należy podkreślić, że rozbieżności w systemach podatkowych poszczególnych stanów w naturalny sposób skutkują występowaniem zjawiska optymalizacji podatkowej w aspekcie międzystanowym. Liberalne podejście do zasad etyki obowiązujących prawników doprowadziło do publikowania $\mathrm{w}$ fachowych czasopismach branżowych artykułów o tytułach zaskakujących dla osób kształconych w systemach sankcjonujących posiadanie chociażby niewielkiej ilości marihuany i to dla celów leczniczych. Warto podać przykład obszernego artykułu "Tax planning for marijuana dealers” („Planowanie podatkowe dla dealerów marihuany”) (Leff 2014, 523-569). W tym kontekście uwypuklenia wymaga fakt, że zalegalizowanie marihuany i nałożenie podatku na czynności dokonywane z jej wykorzystaniem oraz na generowany przez przemysł narkotykowy legalny dochód, nie może być celem samym $\mathrm{w}$ sobie. Zabieg ten musi być dokonany umiejętnie - $\mathrm{z}$ uniknięciem nadmiernego fiskalizmu. W sposób naturalny bowiem podmiot zaangażowany w przemysł narkotykowy będzie starał się wybrać najkorzystniejszą pod względem obciążeń fiskalnych jurysdykcję, w czym uzyska pomoc profesjonalistów. Spostrzeżenie tego rodzaju ma szczególne znaczenie nie tylko dla polityków w Stanach Zjednoczonych, ale także na gruncie europejskim w dobie istnienia swobód unijnych.

\section{PODSUMOWANIE}

Każde państwo członkowskie Unii Europejskiej, które nie zalegalizowało posiadania i zażywania miękkich narkotyków, musi liczyć się z przejęciem potencjalnego, możliwego do nałożenia podatku przez inne, konkurencyjne pod tym względem jurysdykcje, a ponadto z generowaniem kosztów przez funkcjonowanie mechanizmów zwalczających miękkie narkotyki. Umiejętnie dokonane (z uniknięciem nadmiernego fiskalizmu) opodatkowanie działalności narkotykowej przynosi jurysdykcjom wymierne i znaczne korzyści, co zostało wykazane na przykładzie Stanów Zjednoczonych Ameryki Północnej. Doświadczenia stanu Kalifornia są przy tym niezwykle cenne dla Polski i dają obraz przychodu budżetowego, jaki może być wygenerowany z tytułu nałożenia podatków różnego rodzaju na narkotyki miękkie, w społeczeństwie o porównywalnej liczbie ludności ${ }^{10}$.

10 Stan Kalifornia na przełomie lat 2014 i 2015 zamieszkiwało 38 milionów ludzi. Dane za: U.S. Census Bureau. www.census.gov [dostęp 20.04.2015]. 
Legalizacja miękkich narkotyków - w połączeniu z umiejętnie dokonanym procesem nakładania podatków - stanowi szybki, skuteczny i nieoceniony w dobie kryzysu ekonomicznego środek, podjęty w celu wejścia na szlak gorączki złota, której beneficjentami byłyby także struktury publicznoprawne. Zbyt restrykcyjne podejście może bowiem skutkować pogłębianiem się recesji gospodarczej, co zostało zauważone $\mathrm{w}$ doktrynie amerykańskiej w odniesieniu do relacji pomiędzy prohibicją a Wielkim Kryzysem. Należy także podkreślić, iż zakazanie chociażby tylko posiadania marihuany przenosi narkotykowy biznes do szarej strefy. Jeden czyn zabroniony generuje przy tym inny - uzyskanie dochodu z szeroko rozumianego handlu narkotykami (nie tylko bezpośrednio ze sprzedaży narkotyków, ale także powstałego w wyniku pozostawania w relacjach handlowych $\mathrm{z}$ dealerami), powoduje późniejsze zabiegi ukrywające rzeczywiste pochodzenie dochodu. Legalizacja marihuany nie musi przy tym wpłynąć na wzrost ceny dla konsumenta. Jak podnosi się $\mathrm{w}$ doktrynie - podatki należne podmiotowi publicznoprawnemu zajmą bowiem miejsce łapówek oraz wynagradzania ryzyka poniesienia odpowiedzialności karnej oraz administracyjnej (Vitiello 2009, 1374). Ponadto, nawet przy pozostaniu części dealerów w szarej strefie, wielu konsumentów będzie wolało zapłacić wyższą cenę, ale mieć pewność, że kupują bezpieczny produkt (tamże, 1374).

Kwestia legalności narkotyków miękkich w Stanach Zjednoczonych jest niezwykle interesującym przykładem ewolucji zarówno na etapie tworzenia prawa, jak i jego stosowania. Zaobserwowane przejście od wojny, wykorzystującej ciężką jurydyczną artylerię, do daleko idącego przyzwolenia władz stanowych, przy jedynie delikatnym napomnieniu ze strony administracji federalnej, stanowi doskonały obraz zmian możliwych do wprowadzenia w spontaniczny sposób, w stosunkowo krótkim czasie. Normy federalne, choć nadal formalnie obowiązujące, w obliczu bogatego ustawodawstwa stanowego i określonej woli politycznej, zanikają przez desuetudo. W ocenie Autora fiskalne aspekty legalizacji marihuany stanowiły jedną z przyczyn takiego stanu rzeczy, o czym świadczy chociażby złagodzenie praktyki federalnej, zbiegające się w czasie z początkiem kryzysu ekonomicznego.

Problem legalizacji marihuany nazywany bywa ,potworem, którego sami sobie stworzyliśmy" (Gierach 1993, 95). Choć celem niniejszego artykułu nie jest wszechstronne rozważanie zalet i wad legalizacji marihuany, trudno nie zgodzić się z takim stwierdzeniem. Dyskusja sprowadza się w istocie do odpowiedzi na pytanie, czy wspomniana kreacja potwora jest mnożeniem bytów bez potrzeby czy też raczej celowym działaniem, mającym odpowiednie uzasadnienie natury moralnej, społecznej lub zdrowotnej. Odpowiedź powinna zostać udzielona w dyskursie politycznym, w którym fiskalne względy legalizacji marihuany - zabiegu mogącego przynieść budżetowi struktur publicznoprawnych dodatkowy przychód w wysokości nawet 1 miliarda 200 milionów dolarów - stanowią argument trudny do zignorowania, argument, który doprowadził administrację federalną Stanów Zjednoczonych Ameryki Północnej do zaniechania korzystania $\mathrm{z}$ legalnie przyznanych kompetencji. 


\section{BIBLIOGRAFIA}

Borden, David. 2013. "Drug Prohibition and Poverty". The Brown Journal of World Affairs XX (Fall/Winter): 218-243.

Carcieri, Martin D. 2004. "Gonzales v. Reich: An Opening For Rational Drug Law Reform”. Tennessee Journal of Law \& Policy I (3): 307-386.

Echegaray, Margarita Mercado. 2006. "Drug prohibition in America: Federal drug policy and its consequences". Revista Juridica University of Puerto Rico 75 (4): 1215-1276.

Evans, David G. 2013. “The Economic Impacts of Marijuana Legalization”. The Journal of Global Drug Policy and Practice 7(4): 2-40.

Gierach, James E. 1993. "An economic attack on illicit drugs". ABA Journal, May: 94-95.

Hoffman, Morris B. 2000. "The Drug Court Scandal”. North Carolina Law Review 78: 1437-1534.

Johnston, David, Neil A. Lewis. 2009. "Obama Administration to Stop Raids on Medical Marijuana Dispensers". New York Times, March 18.

Kamin, Sam, Eli Wald. 2013. "Marijuana Lawyers: Outlaws or Crusaders?”. Oregon Law Review 91: 869-932.

Leff, Benjamin. 2014. "Tax Planning for Marijuana Dealers”. Iowa Law Review 99: 523-569.

Shasnky, Louis C. 2007. “Gonzales v. Reich: Political Safeguards up in smoke?”. De Paul Law Review 56: 759-798.

Vitiello, Michael. 2009. “Legalizing marijuana: California's pot of gold?". Wisconsin Law Review 6: $1349-1389$.

Yanover, Yori. 2013. "Hezbollah Defending Cannabis Fields Against Rebel Takeover". Jewish Press, July 21.

\section{AKTY PRAWNE}

Colorado Constitution.

Compassionate Use Act, California Health \& Safety Code, § 11362.5(d), West Supp. 2006.

Controlled Substances Act, 21 U.S.C. $\S 801$ et. Seq.

Washington Initiative Measure No. 502, July 8, 2011.

\section{ORZECZNICTWO}

Gonzales v. Reich, 545 U.S. 1. (2005).

People v. Lauria, 251 Cal. App. 2d 471 (Cal. Ct. App. 1967).

\section{INNE WYKORZYSTANE MATERIALY}

U.S. Census Bureau. www.census.gov [dostęp 20.04.2015].

EUROSTAT: ec.europa.eu/eurostat [dostęp 20.04.2015].

Opinia State Bar of Arizona, Formal Op. 11.01(2011). azbar.org [dostęp 20.04.2015]. 


\title{
Artur Tim
}

\section{FISCAL ASPECTS OF SOFT DRUGS LEGALIZATION. EXPERIENCE FROM THE UNITED STATES OF AMERICA}

\begin{abstract}
Over the last few years there has been noticed a change in the approach of the federal administration of the United States of America to the issue of marijuana. There has been done a shift from war absorbing many victims to leaving a decision on legalizing marijuana actually up to the individual states. The Author describes that process, presents controversies caused by a breakthrough judgment in the case of Gonzales v. Reich, analyses a status of lawyers from the drug industry (called "marijuana lawyers"), indicates a tax planning process in the aspect of marijuana trade and shows the scale of gain received by the public structures due to imposing turnover taxes on using marijuana and income taxes on dealers and entities cooperating with them.
\end{abstract}

Keywords: tax planning, marijuana, Gonzales v. Reich, drug industry, marijuana lawyers. 